\title{
COMPARATIVE PROXIMATE COMPOSITION OF MALAYSIAN FERMENTED SHRIMP PRODUCTS
}

\author{
ILYANIE, H.Y. ${ }^{1,2}$, HUDA-FAUJAN, N. ${ }^{*}$ and IDA MURYANY, M.Y. ${ }^{2}$ \\ ${ }^{1}$ Food Biotechnology Programme, Faculty of Science and Technology, Universiti Sains Islam Malaysia, \\ 71800 Nilai, Negeri Sembilan, Malaysia \\ ${ }^{2}$ School of Biology, Universiti Teknologi MARA, Negeri Sembilan Branch, Kuala Pilah Campus, \\ 70450 Kuala Pilah, Negeri Sembilan, Malaysia \\ *E-mail:nurhuda@usim.edu.my
}

Accepted 18 September 2020, Published online 25 October 2020

\begin{abstract}
Two different types of fermented shrimps locally known as belacan and cincaluk are amongst the most common fermented products consumed in Malaysia. Proximate composition of these products were analysed which include moisture, ash, protein, and fat. Total carbohydrate was calculated using difference of the value of each nutrient. Water activity, salt concentration, $\mathrm{pH}$, and colour of each product were also measured for both fermented shrimp product. Results revealed that cincaluk has higher moisture, protein, ash, carbohydrate content, and water activity but lower content of sodium and $\mathrm{pH}$ value in comparison to belacan. The results for both products are also comparable with the other types of fermented shrimp products from different country, respectively.
\end{abstract}

Key words: cincaluk; belacan; fermented shrimps compositions; fermented shrimps properties

\section{INTRODUCTION}

Varieties of fermented foods and beverages are consumed tremendously across the globe and have become very common, where almost all ethnic groups have their own recipes passed from generations to generations (Hui et al., 2004). Fermentation process changes the basic characteristic of a food or raw materials into palatable and acceptable products. It has its own prestige and values as the process could increase the product shelf life, as well as their qualities for instance feel, smell, taste, and colour (Marco et al., 2017). Furthermore, fermentation process may also enhance nutritional value of the food, retain the viable microorganisms and their metabolites, which may give health impact to human host (Hui et al., 2004; Motarjemi, 2002). Besides, fermentation process could contribute to food safety if other facilities related to food preservation are unavailable (Motarjemi, 2002). In fact, numerous studies have been done on myriad benefits of fermented foods (Alu'datt et al., 2018; Kaprasob et al., 2018; Rezac et al., 2018; Haitham et al., 2017; Joshi et al., 2008).

\footnotetext{
* To whom correspondence should be addressed.
}

Fermentation can occur naturally or could be initiated by addition of starter culture to the raw materials (Pongsetkul et al., 2014). Fermented foods are produced from various sources such as cereal grain, vegetables and bamboo shoots, legumes, roots and tubers, dairy products, meats and marine animals (Tamang et al., 2016). Fermented marine products are widely accessible and consumed around the globe as flavor enhancers or condiments. The raw materials used are commonly fishes, shrimps, or oyster. Examples of common fermented shrimp products of the world are ronto and terasi of Indonesia (Khairina et al., 2016; Huda, 2012), saewoojeot of Korea (Kim et al., 2014), ka-pi and Koong-Som of Thailand (Faithong et al., 2010), as well as, cincaluk and belacan of Malaysia.

Belacan and cincaluk (also known as cencalok or chinchalok) are commonly consumed in Malaysia, besides other fermented seafood products such as budu and pekasam. Belacan is produced in all Malaysian state whilst cincaluk production is concerted in Melaka, Malaysia. The making of cincaluk and belacan used small shrimp such as Acetes spp. or Mysid. In belacan production, the shrimps will be washed and mix with salt in certain ratio before it is sun-dried and pounded. The paste 
will be stored into container to start up the fermentation. The process would occur repeatedly until the desired texture is achieved. However, different materials (types of shrimp, percentage of salt) and methods (dry or wet) are involved in the making of cincaluk. The shrimp will be washed before it is combined with salt and cooked rice. The mixture will be inserted into suitable container for a fermentation process (Huda, 2012).

Even though the raw materials are the same, differences in other ingredients used in each product and the fermentation steps could lead to dissimilar nutrient composition of the final products (Pongsetkul et al., 2014). Available reports on proximate composition of belacan showed that the protein contents did not comply with the protein requirement stated in the Malaysian Food Act 1983 (Act 1981) and Regulations (1985) meanwhile no recent reports are available on the proximate composition of cincaluk other than study done by Tee et al. (1997). Thus, this study was conducted to determine the proximate composition and $\mathrm{pH}$ value of belacan and cincaluk, as well as to compare the values with other fermented shrimps from different country.

\section{MATERIALS AND METHODS}

\section{Sample collection}

Belacan and cincaluk were purchased from a market in Negeri Sembilan. Samples were transported to Food Microbiology Laboratory, Universiti Sains Islam Malaysia, Nilai, Negeri Sembilan, Malaysia. Samples were then stored in air-tight sample containers and kept in the refrigerator $\left(4^{\circ} \mathrm{C}\right)$ until analysis. All the chemicals involved in the study are analytical grades which includes petroleum ether, sulphuric acid, and copper Kjeltabs.

\section{Proximate composition determination}

Proximate analysis of samples was carried out using standard method of the Association of Official Analytical Chemists (AOAC, 2005).

\section{Moisture analysis}

Moisture content of samples was determined by drying samples in an oven at $105^{\circ} \mathrm{C}$ until constant weights of crucible with samples are obtained. The percentage of moisture content was measured by calculating difference of wet weight and dry weight of the sample.

\section{Ash analysis}

Determination of total ash content of samples was carried out according to AOAC (2005) method 920.153 using conventional dry-ashing. Initially, dried of $3.0 \mathrm{~g}$ samples were burnt and ashed in a muffle furnace at $525^{\circ} \mathrm{C}$ for $24 \mathrm{hr}$ until a grey mass (ash) formed, and were then cooled in desiccator. The percentage of total crude ash was calculated using following equation.

$$
\text { Crude ash }(\%) \text { dry basis }=\left[\mathrm{W}_{1} / \mathrm{W}_{2}\right] \times 100
$$

Where $\mathrm{W}_{1}$ = weight of samples after ashing; $\mathrm{W}_{2}=$ weight of samples before ashing.

\section{Protein analysis}

Protein content of samples was measured using nitrogen assay based on Kjeldahl method (AOAC, 2005) method 928.08 which include digestion and distillation process. The percentage of crude protein was expressed as total of nitrogen percentage and multiplied by a factor of 6.25 (nitrogen-protein conversion factor for fish and seafood product) as following equation.

Crude protein $(\%)=$ Nitrogen $(\%)$ in samples $\times 6.25$

\section{Fat analysis}

Fat was estimated using Soxhlet extraction with petroleum ether as the solvent. The fat content of each sample was determined after oven-drying the extracted fats overnight (Soxtherm ${ }^{\circledR}$ extractor, C. Gerhardt). The fat content of samples was calculated as following equation.

$$
\text { Fat }(\%)=\left[\left(\mathrm{W}_{1}-\mathrm{W}_{2}\right) / \mathrm{W}_{0}\right] \times 100
$$

Where $\mathrm{W}_{0}=$ weight of sample after treatment; $\mathrm{W}_{1}=$ total weight of extraction beaker with boiling stones and extracted fats; and $\mathrm{W}_{2}=$ total weight of extraction beaker and boiling stones.

\section{Carbohydrate analysis}

Total carbohydrate was calculated using difference of the value of each nutrient using following equation.

$$
\begin{gathered}
\text { Carbohydrates }(\%)=100-[\text { Moisture }(\%)+\text { Ash }(\%) \\
+ \text { Protein }(\%)+\text { Fat }(\%)]
\end{gathered}
$$

\section{Water activity measurement}

Water activity $\left(A_{w}\right)$ of each sample was determined using Aqua Lab Dew Point Water Activity Meter 4TE (Decagon, Pullman, WA, USA) at about $25^{\circ} \mathrm{C}$. The samples were placed into the cup before it is being distributed according to manufacturer's instruction.

\section{Sodium content measurement}

The sodium content of samples was determined using ICP-OES and ICP-MS method according to manufacturer's instruction. 


\section{pH analysis}

The measurement of $\mathrm{pH}$ of samples was done using Mettler Toledo $\mathrm{pH}$ meter. Prior to analysis, $10 \mathrm{~g}$ of belacan sample were mixed with $2 \mathrm{~mL}$ distilled water to create a paste-like structure (Vijayakumar \& Adedeji, 2017), whilst pH of cincaluk was measured directly to the sample in a small beaker.

\section{Colour measurement of samples}

Determination of colour of samples was done using colorimeter (LabScan $\AA$ XE Spectrophotometer Model, HunterLab) based on $L^{*} a^{*} b^{*}$ colour scale system. $L^{*}$ value represents lightness/darkness, $a^{*}$ value represent redness/greenness, and $b^{*}$ value represents yellowness/ blueness and was measured according to the manufacturer's instruction.

\section{Statistical analysis}

Statistical analysis of the data was carried out using SPSS (Statistical Package for the Social Sciences) version 24.0. Independent T-test was used to measure significant differences in between values of both samples. A significant difference was considered at the level $p<0.05$.

\section{RESULTS AND DISCUSSION}

\section{Proximate composition of samples}

The proximate compositions of belacan and cincaluk which include moisture, fat, protein and ash are shown in Table 1. Proximate composition of belacan and cincaluk were found significantly differed $(p<0.05)$ excluding the fat content. Even though the moisture content of cincaluk obtained in this study $(67.44 \%)$ was slightly lower than the study done by Tee et al. (1997), the value was significantly higher $(p<0.05)$ compared to belacan $(32.16 \%)$. The moisture value of belacan was almost in the same range as ka-pi (Faithong et al., 2010) and saewoojeot (Kim et al., 2014), and it complies with the water content stated in the Malaysian Food Act 1983 (Act 1981) and Regulations (1985)
$(<40 \%)$. The high moisture content of cincaluk might be contributed by addition of cooked rice and tomato sauce in the ingredient (Huda, 2012). It might also be attributed by washing procedure and water retention that happens during fermentation process (Rapsang \& Joshi, 2013), as well as other manufacturing steps (Kim et al., 2014). However, the highest moisture content in fermented shrimp products have been reported by Koong-Som which ranged between 73.35 and $80.71 \%$ (Faithong et al., 2010). Palm-sap-sugar concentrate that is mixed with shrimps to produce Koong-Som may cause the highest range of moisture content of the products, compared to the other type of samples.

The ash content signifies the presence of mineral in the food that are not destroyed by high temperature (Siti Mahirah et al., 2018). Fresh shrimps itself is abundant in mineral contents, which are significant in maintaining various functions of living organisms (Ajifolokun et al., 2018). According to Malaysian Food Act 1983 (Act 1981) and Regulations (1985), ash content in belacan shall be less than $30 \%$ whilst cincaluk shall contain not more than $15 \%$ of ash. Based on this study, it was found that ash was a major component in belacan and cincaluk (dry weight basis). Extrapolation of data to wet weight basis showed that ash content in belacan and cincaluk are approximately $38.09 \%$ and $14.32 \%$, respectively, with the former did not comply to the regulations. Since high salt content is used in the fermentation process (Pongsetkul et al., 2014), it contributed to high ash content of both belacan and cincaluk. As Koong-Som contained the highest moisture content, it reflects the least ash content compared to the other fermented shrimp products.

Protein content in fermented foods possibly will show slight decrease compared to fresh material as microorganisms involved in fermenting the food may produced proteolytic enzymes (Rapsang \& Joshi, 2013). Besides, extended fermentation period may also cause rigorous degradation of proteins (Faithong et al., 2010). Results obtained in this study found that protein content in belacan was

Table 1. Proximate composition of belacan and cincaluk

\begin{tabular}{ccc}
\hline \multirow{2}{*}{ Proximate composition (\%) } & \multicolumn{2}{c}{ Samples } \\
\cline { 2 - 3 } & Belacan & Cincaluk \\
\hline Moisture & $32.16 \pm 2.00^{*}$ & $67.44 \pm 0.52$ \\
Ash & $56.15 \pm 0.56(\text { d.w. })^{*}$ & $43.97 \pm 1.39$ (d.w.) \\
Protein & $31.83 \pm 0.66$ (d.w.) $^{*}$ & $34.22 \pm 0.47$ (d.w.) \\
Fat & $1.01 \pm 0.23$ (d.w.) $^{2}$ & $2.38 \pm 0.95$ (d.w.) \\
\hline
\end{tabular}

a) Value for belacan and cincaluk represents the mean of triplicates \pm SD experiment.

b) ${ }^{*}=$ indicate means are significantly different between belacan and cincaluk at $p<0.05$.

c) d.w. = dry weight basis. 
$31.83 \%$ whilst cincaluk contained $34.22 \%$ protein $(p<0.05)$. In fact, Malaysian Food Act 1983 (Act 1981) and Regulations (1985) stated that belacan and cincaluk shall contain not less than $30 \%$ and $10 \%$ protein, respectively. The protein content in belacan when extrapolated to wet weight showed value that did not comply to the regulation $(21.59 \%)$, which in agreement with the previous report done by Sharif et al. (2008). However, the extrapolated protein content value for cincaluk $(11.14 \%)$ are slightly higher than the stated values.

Even though the moisture content was significantly $(p<0.05)$ dissimilar, fat content in cincaluk $(2.38 \%)$ is nearly comparable $(p>0.05)$ to belacan $(1.01 \%)$. Contrary to the outcome of the present study, Ajifolokun et al. (2018) suggested that fat content is negatively correlated with water content. Nevertheless, the values obtained in this study are in agreement with other fermented shrimps reported by Faithong et al. (2010), Kim et al. (2014) and Khairina et al. (2016), excluding saewoojeot with slightly higher in fat content. The fat content of fermented shrimp products might be contributed by polyunsaturated fatty acid content in the shrimp oil (Pongsetkul et al., 2014).

Carbohydrate content will be reduced in fermented foods in comparison to fresh materials as the biomolecules are used by microorganisms in the fermentation process (Rapsang \& Joshi, 2013). In a recent study, Ajifolokun et al. (2019) reported the carbohydrate content in sun-dried and oven-dried shrimps was approximately between 18.40 and $25.17 \%$. In general, belacan is produced without addition of any carbon source, differ from cincaluk which has cooked rice as one of its contents. Thus, the ingredients correlate to the significant different $(p<0.05)$ in carbohydrate contents of both products. Belacan contained $11.01 \%$ carbohydrate content; rather lower than cincaluk (19.43\%). This might also be due to various carbon sources that are added as exact ingredients or deliberately added to increase the yield and reduce the cost (Faithong et al., 2010).

\section{Chemical properties of samples}

Table 2 shows the chemical properties of belacan and cincaluk include water activity, sodium content, and $\mathrm{pH}$ value of belacan and cincaluk.
The water activity of belacan was 0.723 which was slightly lower than that of cincaluk (0.823). The results for belacan are almost comparable to Bruneian fermented paste (0.728) and Korean dried shrimp paste (0.771) (Kim et al., 2014). Meanwhile, $K a-p i$ from various sources showed water activity values between 0.64 and 0.72 (Daroonpunt et al., 2016). In food preservation method, active water is more important in the stability of food compared to the total amount of water present. Water activity can be reduced or regulated by various approaches such as addition of solutes or removal of water. Pathogens may not grow in food with water activity below 0.85 to 0.86 (Shafiur Rahman \& Labuza, 2007).

In the assessment of sodium content, it was found that belacan contained a high salt content $(10104.13 \mathrm{mg} / 100 \mathrm{~g})$ which doubled the value of cincaluk $(5246.34 \mathrm{mg} / 100 \mathrm{~g})$. This was probably due to the process in belacan making which adds a massive amount of salt contrasted to the making of cincaluk. The salt content was in line with extrapolated ash content to wet weight basis. Findings from Faithong et al. (2010) also suggested that $K a-p i$, which have the comparable feature as belacan contains higher percentage of salt compared to Koong-Som. Salting helps to reduce active water and causes the cells to shrink, thus converts fresh ingredients into products that are more shelf-stable (Shafiur Rahman \& Labuza, 2007).

Belacan recorded the basic $\mathrm{pH}$ (7.31) which are slightly similar to Ka-pi (Faithong et al., 2010), Bruneian shrimp paste, and Saewoojeot (Kim et al., 2014). This may be due to the used of raw materials and processes that are slightly comparable. All four fermented shrimp product used only shrimps and salts as its ingredients. The slightly basic $\mathrm{pH}$ may be due to the formation of ammonia during fermentation process (Faithong et al., 2010). Nonetheless, cincaluk presented acidic pH (4.96) $(p<0.05)$ from belacan. Other types of fermented shrimps which contains other raw materials as their ingredients also showed acidic pH, eg. Koong-Som (Faithong et al., 2010) and Ronto (Khairina et al., 2016), with the latter using rice as carbohydrate sources. Thus, with the addition of more carbon sources, it could stimulate more growth of micro-

Table 2. Water activity, sodium content, and $\mathrm{pH}$ values of belacan and cincaluk

\begin{tabular}{ccc}
\hline \multirow{2}{*}{ Chemical properties } & \multicolumn{2}{c}{ Samples } \\
\cline { 2 - 3 } & Belacan & Cincaluk \\
\hline Water activity & 0.723 & 0.823 \\
Sodium content $(\mathrm{mg} / 100 \mathrm{~g})$ & 10104.13 & 5246.34 \\
$\mathrm{pH}$ & 7.31 & 4.96 \\
\hline
\end{tabular}




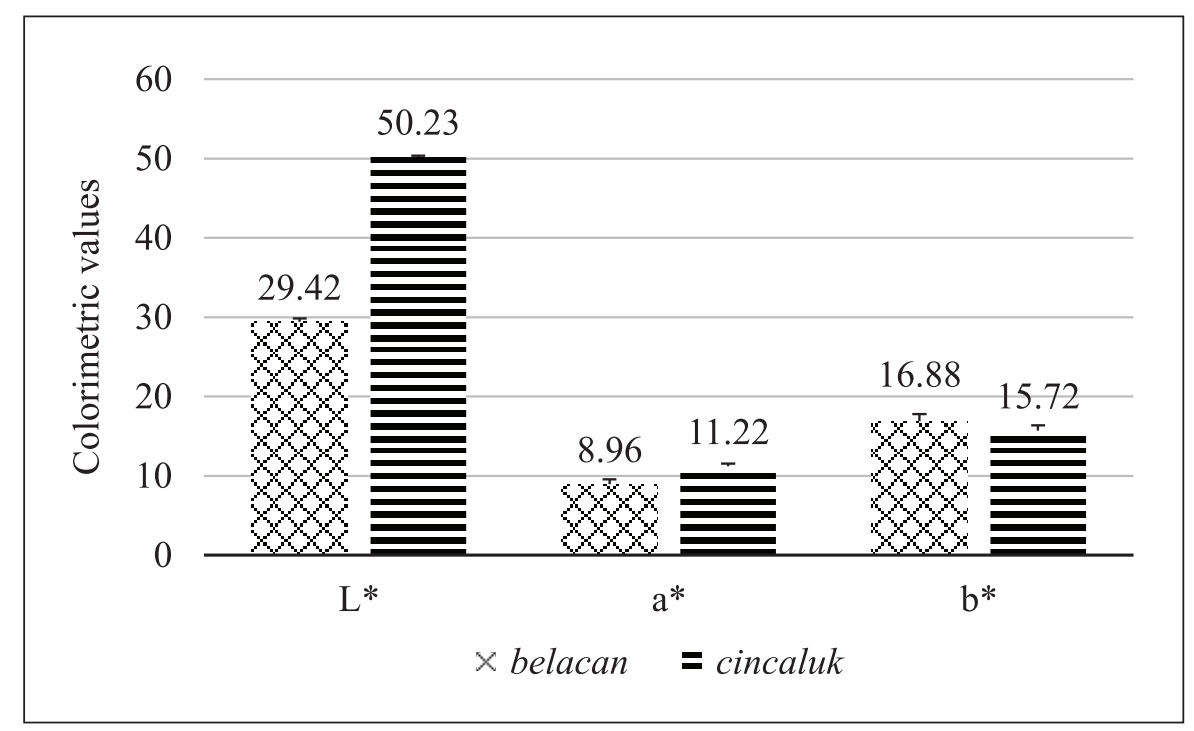

Fig. 1. Hunter $L, a, b$ colorimetric values of belacan and cincaluk.

organisms (Khairina et al., 2016). Theoretically, $\mathrm{pH}$ in fermented foods will be slightly lower as fermentation progression might produce various organic acids, for example lactic acid, acetic acid, and propionic acid (Erkmen \& Bozoglu, 2016). Common microorganisms that can be isolated from fermented foods are yeast and lactic acid bacteria. Low $\mathrm{pH}$ environment is also beneficial in terms of suppression of pathogens growth (Chiang et al., 2006). However, $\mathrm{pH}$ changes may occur depending on the methods used during the manufacturing (Kim et al., 2014).

\section{Colour of samples}

Figure 1 shows the Hunter $L, a, b$ colorimetric values of belacan and cincaluk. It was found that belacan provided darker colour $(29.42)(p<0.05)$ than cincaluk (50.23). However, the $a^{*}$ (redness/ greenness) and $b^{*}$ (yellowness/blueness) values are almost parallel to each other. Even though both products make use of shrimps as their main ingredients, types of shrimps used, the process and other ingredients added could affect the colours of the end products. Besides, the chemical reactions involved for example oxidation, hydrolysis, and Maillard reaction could contribute to the product's colour development (Daroonpunt et al., 2016).

\section{CONCLUSION}

The proximate composition values of different type of fermented shrimps are diverse depending on the ingredients and fermentation procedures involved in the making of each products. Belacan and cincaluk may become a good source of nutrient as it contains high protein contents and low in fat contents.
However, as ash content is slightly high, a review on the manufacturing procedures are needed to ensure that each values is in accordance with range suggested by Malaysian Food Act 1983 (Act 1981) and Regulations (1985).

\section{ACKNOWLEDGEMENTS}

The author acknowledge the financial support provided by USIM Short Grant (PPP/USG-0216/ FST/30/19216). The author also extend their thanks to Institute of Halal Research \& Management (IHRAM), Universiti Sains Islam Malaysia for providing the laboratory facility to carry out the present study. Special appreciations to Mr. Mohd Zuhaifah Muhamed Jamil, Miss Wan Kamilah Wan Ibrahim, Mrs. Norhafiza Abdul Ghafar, and Mrs. Normah Haron for their assistance.

\section{REFERENCES}

Ajifolokun, O.M., Basson, A.K., Osunsanmi, F.O. \& Zharare, G.E. 2018. Effects of drying methods on quality attributes of shrimps. Journal of Food Processing \& Technology, 10(772): 2-5.

Alu'datt, M.H., Rababah, T., Sakandar, H.A., Imran, M., Mustafa, N., Alhamad, M.N., Mhaidat, N., Kubow, S., Tranchant, C., Al-Tawaha, A.R. \& Avadi, W. 2018. Fermented food-derived bioactive compounds with anticarcinogenic properties: fermented royal jelly as a novel source for compounds with health benefits. In: Akhtar M., Swamy M. (Eds.) Anticancer Plants: Properties and Application. Springer, Singapore. 
AOAC (Association of Official Analytical Chemists). 2005. Official Methods of Analysis. 18th Ed. Washington D.C., Washington.

Chiang, Y.W., Chye, F.Y. \& Mohd Ismail, A. 2006. Microbial diversity and proximate composition of Tapai, a Sabah's fermented beverage. Malaysian Journal of Microbiology, 2(1): 1-6.

Daroonpunt, R., Uchino, M., Tsujii, Y., Kazami, M., Daiki, O. \& Tanasupawat, S. 2016. Chemical and physical properties of Thai traditional shrimp paste (Ka-pi). Journal of Applied Pharmaceutical Science, 6(05): 58-62.

Erkmen, O. \& Bozoglu, T.F. 2016. Food Microbiology: Principles into Practice. John Wiley \& Sons, Ltd., Chichester.

Faithong, N., Benjakul, S., Phatcharat, S. \& Binsan, W. 2010. Chemical composition and antioxidative activity of Thai traditional fermented shrimp and krill products. Food Chemistry, 119(1): 133-140.

Haitham, A.R., Zaiton, H., Norrakiah, A.S. \& HudaFaujan, N. 2017. Assessment of potential probiotic properties lactic acid bacteria from shrimp paste or belacan. International Journal of Advances in Science Engineering and Technology, 5(1): 90-98.

Huda, N. 2012. Malaysian fermented fish product. In: Hui, Y.H. Handbook of Animal-Based Fermented Food and Beverage Technology. 2nd Ed. CRC Press, Taylor \& Francis Group, Boca Raton, FL.

Hui, Y.H., Meunier-Goddik, L., Hansen, Å.S., Josephsen, J., Nip, W.K., Stanfield, P.S. \& Toldra, F. 2004. Handbook of Food and Beverage Fermentation Technology. Marcel Dekker, Inc., New York.

Joshi, S., Bharucha, C. \& Desai, A.J. 2008. Production of Biosurfactant and antifungal compound by fermented food isolate Bacillus subtilis 20B. Bioresource Technology, 99(11): 4603-4608.

Kaprasob, R., Kerdchoechuen, O. \& Laohakunjit, N. 2018. Changes in physico-chemical, astringency, volatile compounds and antioxidant activity of fresh and concentrated cashew apple juice fermented with Lactobacillus plantarum. Journal of Food Science and Technology, 55(10): 3979-3990.

Khairina, R., Fitrial, Y., Satrio, H. \& Rahmi, N. 2016. Physical, chemical, and microbiological properties of "Ronto" a traditional fermented shrimp from South Borneo, Indonesia. Aquatic Procedia, 7: 214-220.

Kim, Y-B., Choi, Y-S., Ku, S-K., Jang, D-J., Ibrahim, H.H. \& Moon, K.B. 2014. Comparison of quality characteristics between belacan from Brunei Darussalam and Korean shrimp paste. Journal of Ethnic Foods, 1(1): 19-23.
Malaysian Food Act 1983 (Act 281) and Regulation. 1985. International Law Book Services, Kuala Lumpur.

Marco, M.L., Heeney, D., Binda, S., Cifelli, C.J., Cotter, P.D., Foligné, B., Gänzle, M., Kort, R., Pasin, G., Pihlanto, A., Smid, E.J. \& Hutkins, R. 2017. Health benefits of fermented foods: microbiota and beyond. Current Opinion in Biotechnology, 44: 94-102.

Motarjemi, Y. 2002. Impact of small scale fermentation technology on food safety in developing countries. International Journal of Food Microbiology, 75(3): 213-229.

Pongsetkul, J., Benjakul, S., Sampavapol, P., Osako, K. \& Faithong, N. 2014. Chemical composition and physical properties of salted shrimp paste (Ka-pi) produced in Thailand. International Aquatic Research, 6(3): 155-166.

Rapsang, G.F. \& Joshi, S.R. 2013. Molecular and probiotic functional characterization of Lactobacillus spp. associated with traditionally fermented fish, Tungtap of Meghalaya in Northeast India. Proceedings of the National Academy of Sciences, India Section B: Biological Sciences, 85(4): 923-933.

Rezac, S., Kok, C.R., Haermann, M. \& Hutkins, R. 2018. Fermented foods as a dietary source of live organisms. Frontiers in Microbiology, 9: 1785.

Shafiur Rahman, M. \& Labuza, T.P. 2007. Water activity and food preservation. In: M. Shafiur Rahman, Handbook of Food Preservation. CRC Press, Taylor and Francis Group, Boca Raton, FL.

Sharif, R., Ghazali, A.R., Rajab, N.F., Haron, H. \& Osman, F. 2008. Toxicological evaluation of some Malaysian locally processed raw food products. Food and Chemical Toxicology, 46(1): 368-374.

Siti Mahirah, Y., Rabeta, M.S. \& Antora, R.A. 2018. Effects of different drying methods on the proximate composition and antioxidant activities of Ocimum basilicum leaves. Food Research, 2(5): 421-428.

Tamang, J.P., Watanabe, K. \& Holzapfel, W.H. 2016. Diversity of microorganisms in global fermented foods and beverages. Frontiers in Microbiology, 7: 377 .

Tee, E.S., Noor, M.I., Azudin, M.N. \& Idris, K. 1997. Nutrient Composition of Malaysian Foods. 4th Ed. Institute for Medical Research, Kuala Lumpur.

Vijayakumar, P. \& Adedeji, A. 2017. Measuring the $\mathrm{pH}$ of food products. University of Kentucky College of Agriculture Food and Environment Cooperative Extension Service, Issued 7: ID246. 